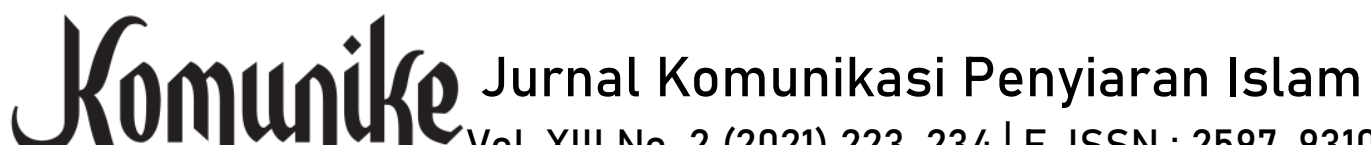 Vol. XIII No. 2 (2021) 223-234 | E-ISSN : 2597-9310
}

Submission : 31 - 12 - 2021 |Revisions : 02 - 01 - 2022| DOI: 10.20414/jurkom.v13i2.4561

\section{TELAAH PESAN DAKWAH DALAM FILM TILIK (STUDI ANALISIS SEMIOTIKA)}

\author{
Muhamad Bisri Mustofa ${ }^{(1)}$, Siti Wuryan, Syamzakiah Rahmayeni \\ UIN Raden Intan Lampung \\ ${ }^{(1)}$ bisrimustofa@radenintan.ac.id
}

\begin{abstract}
Along with the development of the times and technology, of course there are many things that must be addressed in carrying out da'wah activities so that they are in accordance with the development of today's society. This includes the use of various existing media for da'wah purposes, both in print, internet and electronic media which are considered more effective and efficient in conveying da'wah messages, one of which is film. The focus of the problem to be studied is what are the da'wah messages contained in the film Tilik Karya Wahyu Agung Prasetyo. The purpose of this study was to determine the messages of da'wah contained in the film. This study uses a qualitative method. This type of research is library research. The data were then analyzed using Roland Barthes' Semiotics which emphasized two levels of signification, namely the denotation stage and the connotation stage. The results of this study indicate that the Tilik film contains da'wah messages which include creed, sharia, and morals.
\end{abstract}

Keywords: Semiotic, Da'wah Messages, Movies, Tilik

\begin{abstract}
Abstrak
Dakwah bisa ditinjau melalui berbagai media, tidak terkecuali dari Film. Dalam sebuah Film terdapat pesan yang akan disampaikan, terkhusus untuk Film "Tilik". Film ini adalah film yang diproduksi oleh Ravacana Film, dan memiliki Viewers di Youtube sampai 26 juta lebih. Hal ini yang menjadi ketertarikan penulis untuk menganalisis Pesan Dakwah dalam Film karya Wahyu Agung Prasetyo. Fokus masalah yang akan diteliti adalah pada pesan dakwah yang terkandung dalam film Tilik Karya Wahyu Agung Prasetyo. Tujuan penelitian ini adalah untuk mengetahui pesan-pesan dakwah yang ada dalam film tersebut. Jenis penelitian merupakan penelitian pustaka (library research). Data kemudian dianalisis menggunakan Semiotika Roland Barthes yang menekankan pada dua tingkat dalam pertandaan, yaitu tahap denotasi dan tahap konotasi. Hasil penelitian ini dalam Film Tilik terdapat pesan dakwah yang meliputi akidah, syariah, dan akhlak yang dapat menjadi pelajaran bagi masyarakat.
\end{abstract}

Kata Kunci: Semiotika, Pesan Dakwah, Film, Tilik

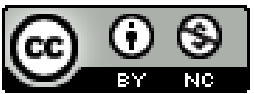

Lisensi

Creative Commons Attribution-NonCommercial 4.0 International License 


\section{A. PENDAHULUAN}

Dakwah mempunyai arti mengajak, menyeru atau seruan untuk mempelajari dan mengamalkan ajaran agama islam. Menurut Toha Yahya Oemar mengatakan bahwa dakwah adalah mengajak manusia dengan cara bijaksana kepada jalan yang benar sesuai dengan perintah Tuhan untuk kemaslahatan dan kebahagiaan mereka dunia dan akhirat. ${ }^{1}$ Dakwah juga berarti suatu upaya mengubah dari situasi tidak baik kepada situasi yang lebih baik sesuai dengan ajaran Islam. Seperti yang telah dituliskan dalam Al-Quran surat Ali-Imran ayat 104 yang berbunyi :

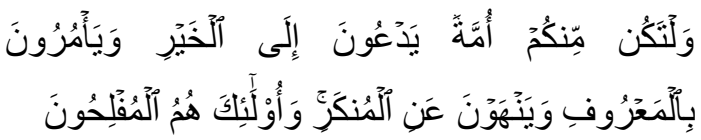

Artinya : "Dan hendaklah ada di antara kamu segolongan umat yang menyeru kepada kebajikan, menyuruh kepada yang ma'ruf dan mencegah dari yang munkar, dan merekalah orangorang yang beruntung".

Dalam ayat tersebut merupakan petunjuk dari Allah kepada kaum mukmin, yakni hendaknya di antara mereka ada segolongan orang yang mau berdakwah dan mengajak manusia ke dalam agama-Nya. Akan tetapi, ada

1 M. Munir \& Wahyu Ilaihi, Manajemen Dakwah, (Jakarta: Kencana, 2006), hlm 20. kecenderungan dalam masyarakat kita bahwa berdakwah hanyalah tugas guru agama, ulama, ustadz atau kyai saja. Padahal setiap muslim mempunyai kesempatan untuk menyampaikan ajaran agama, mengajak berbuat baik dan mencegah berbuat yang munkar.

Selama ini dakwah identik dengan ceramah melalui lisan. Tetapi seiring berkembangnya zaman, dakwah mulai memanfaatkan berbagai media yang ada. Pada era globalisasi sekarang ini, tentu banyak yang harus dibenahi dalam melakukan aktivitas dakwah supaya sesuai dengan perkembangan media informasi masyarakat saat ini. Termasuk penggunaan berbagai dimensi untuk kepentingan dakwah yaitu komunikasi, psikologi, public relations, jurnalistik, tradisi kepenulisan, manajemen, seni, media mutakhir (elektronik seperti film, sinetron, internet) untuk kepentingan dakwah islam. $^{2}$

Film adalah media masa sebagai sarana komunikasi dan penyampaian informasi. Film digunakan sebagai cara menyebarkan berbagai nilai-nilai diantaranya Nilai Agama, dan Sosial bagi masyarakat. Film merupakan salah satu media massa yang dapat menarik minat penonton dalam menyerap

2 Bambang S, Ma'arif Komunikasi Dakwah, (Simbiosa Rekatama Media: 2010), hlm 12 
informasi dan pesan yang disampaikan tidak terkecuali nilai-nilai keagamaan. Pesan yang diutarakan dalam film untuk khalayak dalam bentuk audio visual yang disertai dengan gerak. Film merupakan karya cipta seni dan budaya yang juga salah satu media komunikasi massa beruoa audio visual dibuat berdasarkan asas sinematografi yang direkam pada pita seluloid, pita video, dan bahan hasil proses elektronik, atau proses lainnya, dengan atau tanpa suara yang dapat dipertunjukkan atau ditayangkan dengan sistem proyeksi mekanik, elektronik, dan sisitem lainnya (UU No. 8 tahun 1992).

Film dapat berpengaruh bagi kehidupan manusia, karena membuat penonton seolah-olah mengalami sendiri adegan-adegan dalam film. Pesan-pesan yang termuat dalam setiap adegan film akan memberikan ingatan dan kesan tersendiri bagi masing-masing penonton. Film dapat dikatakan sebagai media komunikasi yang efektif karena menggunakan bahasa verbal maupun non-verbal. Dengan perkembangan media masa yang pesat membuat jangkauan film semakin meluas. Seiring berkembangnya waktu, film dapat dengan mudah dinikmati oleh siapapun tanpa batasan usia. Tak jarang sebuah film dibuat berdasarkan kebiasaan yang dilakukan dalam kehidupan sehari-hari suatu masyarakat. Salah satu film yang mengandung cerita yang dekat dengan kehidupan masyarakat adalah Tilik

Salah satu media yang digunakan untuk menyampaikan pesan adalah film. Film merupakan media massa yang dinilai efektif dalam menyampaikan pesan dibandingkan dengan media komunikasi yang lainnya. Karena unsurunsur dalam film sama dalam kehidupan sebenarnya, seakan-akan para penikmat film menganggap bahwa film yang mereka lihat adalah nyata dan dapat dirasakan sesuai dengan keadaan mereka saat itu. Film bisa menjadi tontonan yang menghibur serta bisa menyelipkan pesan-pesan dakwah secara kreatif dan mampu menyentuh penonton tanpa berkesan menggurui.

Film yang menjadi perhatian penulis adalah film pendek yang berjudul Tilik. Dalam film tersebut menceritakan serombongan ibu-ibu menjenguk Ibu Lurah mereka yang dirawat di rumah sakit menggunakan truk. Di sepanjang perjalanan diisi oleh ocehan Ibu Tedjo yang mengumbar keburukan tentang gadis desa bernama Dian, informasi keburukan tentang Dian tersebut Ia dapatkan dari media sosial. Namun tidak semua yang disampaikan oleh $\mathrm{Bu}$ Tedjo diterima begitu saja, 
sebab ada $\mathrm{Yu}$ Ning yang mengingatkan untuk tidak menerima informasi begitu saja tanpa tahu sumbernya darimana, sampai akhirnya terjadilah adu mulut diantara keduanya. Film ini mendapat pujian dari penonton dan juga para sineas mengenai sinematografi dan akting para pemeran dalam film tersebut.

Namun, film ini juga menuai kontroversi karena menggambarkan perempuan secara tidak pantas. Beberapa kritikus menilai film Tilik menggambarkan perempuan senang bergosip yang kebenarannya belum dibuktikan. $^{3}$

Selain karena mendapat pujian dan menuai kontroversi, penulis tertarik meneliti film Tilik karena film ini menceritakan fenomena yang ada di masyarakat serta menyajikan realita kehidupan sehari-hari, seperti budaya menjenguk orang sakit, fenomena ibuibu yang suka bergosip dan maraknya informasi hoax. Meski film tersebut mengangkat cerita yang sangat sederhana namun cukup jelas dalam penyampaian pesan dari film itu sendiri. Film Tilik memperlihatkan pesan-pesan dakwah di beberapa adegannya. Banyak pelajaran yang dapat diambil seperti

3 Ayesha Muna, 28 Agustus 2020, Melihat perlawanan stereotip perempuan Indonesia di film pendek Tilik, https://theconversation.com/, Diakses 06 Juli 2021 jangan mudah percaya dengan informasi-informasi di media sosial tanpa tahu darimana sumbernya dan jangan membicarakan keburukan orang lain karena sesungguhnya seperti memakan bangkai saudaranya sendiri. Allah Swt berfirman dalam surat AlHujurat Ayat 12:

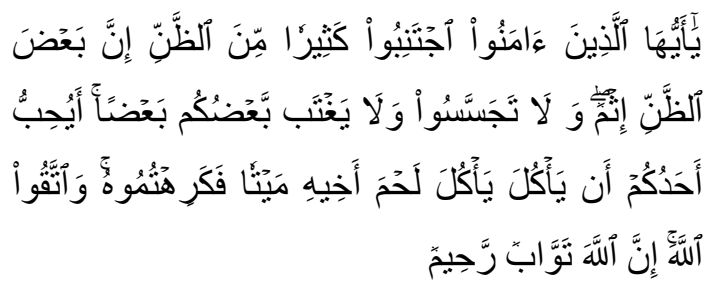

Artinya : "Wahai orang-orang yang beriman! Jauhilah banyak dari prasangka, sesungguhnya sebagian prasangka itu dosa dan janganlah kamu mencari-cari kesalahan orang lain dan janganlah ada di antara kamu yang menggunjing sebagian yang lain. Apakah ada di antara kamu yang suka memakan daging saudaranya yang sudah mati? Tentu kamu merasa jijik. Dan bertakwalah kepada Allah, sesungguhnya Allah Maha Penerima tobat, Maha Penyayang”.

Dalam beberapa scene dalam film tersebut menampilkan beberapa adegan dan dialog yang mengandung pesan dakwah baik dari segi aqidah, syariah maupun akhlak. Pada setiap film tentunya mempunyai makna tersendiri 
baik secara tersirat maupun tersurat yang disampaikan sineas kepada penontonnya. Namun, tidak semua pesan yang ada dalam film dapat tersampaikan kepada penonton.

Pesan dapat terbaca dengan adanya sebuah penelitian yang lebih mendalam mengenai film tersebut. Maka dari itu, pentingnya Analisis Semiotika terhadap Pesan Dakwah dalam Film Tilik.

\section{B. LITERATURE REVIEW}

Adapun beberapa penelitian terdahulu terkait Analisis Semiotik diataranya Nurul Latifah, mahasiswa program studi Komunikasi dan Penyiaran Islam UIN Syarif Hidayatullah Jakarta 2016 dengan judul "Analisis Semiotika Pesan Dakwah Dalam Film Bulan Terbelah di Langit Amerika". ${ }^{4}$ Masalah yang dikaji dalam skripsi ini adalah bagaimana pesan dakwah di dalam film Bulan Terbelah di Langit Amerika baik dalam makna denotatif maupun makna konotatif. Penelitian ini menggunakan penelitian kualitatif dengan metode semiotik. Perbedaan penelitian yang dilakukan oleh Nurul Latifah terletak kepada analisisnya. Nurul Latifah menganalisis

4 Nurul Latifah, "Analisis Semiotika Pesan Dakwah Dalam Film Bulan Terbelah di Langit Amerika" (Skripsi S1 Fakultas Dakwah dan Ilmu Komunikasi, Jurusan Komunikasi dan Penyiaran Islam, 2016) pesan dakwah dalam film Bulan Terbelah di Langit Amerika dengan fokus temuan pada pesan syariah saja, sedangkan penulis menganalisis semua pesan dakwah baik akidah, syariah dan akhlak.

Selanjutnya oleh Mohamad Ihwan Fikri, mahasiswa program studi Komunikasi dan Penyiaran Islam UIN Raden Intan Lampung 2019 dengan judul "Pesan Dakwah Dalam Film Hafalan Sholat Delisa Karya Sony Gaokasak". 5 Masalah yang dikaji dalam skripsi ini adalah bagaimana pesan dakwah di dalam film Hafalan Shalat Delisa.

Penelitian ini menggunakan penelitian kualitatif dengan metode semiotik. Perbedaan penelitian yang dilakukan oleh Mohamad Ihwan Fikri terletak pada analisisnya, ia fokus analisis pada tanda suara dan dialog yang diucapkan sedangkan penulis dalam hal ini menganalisis dialog maupun adegannya.

Penelitian lainnya dilakukan oleh Dwi Ratih dalam Jurnal Semiotika dengan Judul Nilai Sosial Budaya dalam Film Tilik. Berdasarkan analisis yang

\footnotetext{
${ }^{5}$ Mohamad Ihwan Fikri, "Pesan Dakwah Dalam Film Hafalan Sholat Delisa Karya Sony Gaokasak" (Skripsi S1 Fakultas Dakwah dan Ilmu Komunikasi, Jurusan Komunikasi dan Penyiaran Islam, 2019)
} 
Komunike, Volume XIII, No. 2 Desember 2021

telah dilakukan menggunakan pendekatan semiotik Charles Sanders Peirce maka ditemukan banyak data yang menunjukkan nilai sosial dan kebudayaan sistem bahasa, sikap kekeluargaan, organisasi sosial, kemajuan teknologi, sistem mata pencaharian, sistem religi, sapaan, mitos yang berkembang dalam masyarakat, status sosial, gotong royong, dan nilai sopan santun. Perbedaan dengan penelitian ini terdapat pada hal yang dikaji, yaitu peneliti lebih mencari pesan dakwah dari setiap adegan yang dilakukan dalam Film Tilik yang di kaitkan dengan Al-Qur'an dan Hadits. Hal tersebut dapat dilihat melalui datadata temuan yang telah dihadirkan dalam penelitian. $^{6}$

Selanjutnya Jurnal yang di tulis oleh Aditya Ramadhani tentang Permainan Bahasa dan Analisis Semiotika pada Dialog Film Pendek Tilik, Hasil penelitian menunjukkan bahwa linguistic aspek, yaitu semantik dan fonologi, mendukung humor dan alur cerita ketegangan dalam film pendek 'Tilik.' Aspek semantik yang ditemukan adalah peribahasa, metafora, polisemi, silogisme, sinonim, antonim.

${ }^{6}$ Dwi Ratih Puspitasari, Nilai Sosial Budaya dalam Film Tilik (Kajian Semiotika Charles Sanders Peirce), Jurnal SEMIOTIKA, Vol. 15 (1), $10-18$

\footnotetext{
7 Aditya Ramadhani Tirtamenda, Permainan Bahasa dan Analisis Semiotika Pada Dialog Film Tilik, Jurnal Lugas, Vol. 5 (1), 1-9
} homonim, metatesis, dan pengulangan bunyi. $^{7}$ Sedangakan perbedaan yang menonjol dalam penelitian yang penulis lakukan adalah tertuju pada Pesan Dakwah yang di tampilkan dari setiap adegan dalam Film Tilik.

Kemudian, Jurnal yang ditulis oleh Dian Bagus Mitreka Satata, Methania Aris Shusantie, Analisis Hubungan Interpersonal dalam Film Tilik pada Persfektif Psikologis, Dinamika Sosial Budaya Jurnal, Vol. 23 (1) menganalisa Film Tilik pada perspektif teori psikologi hubungan interpersonal. Berbagai sudut pandang teori psikologi mengungkapkan dinamika interaksi sosial sepanjang alur cerita. Banyak terjadi konflik dalam cerita dan gangguan secara psikologis yang terjadi selama proses interaksi kelompok berlangsung sehingga memicu emosi setiap menonton karena timbul prasangka dan steorotip pada kelompok masyarakat. Perbedaan yang signifikan dari pesan yang di bahas penulis adalah aspek akidah, Syariah dan akhlak yang dapat dijadikan sebagai ukuran baik bagi masyarakat bukan pada psikologi tokoh utama. 


\section{METODE PENELITIAN}

Berdasarkan setting penelitian, maka penelitian ini digolongkan pada jenis penelitian pustaka (library research). Yaitu penelitian yang digali lewat kepustakaan (literatur). Supaya penelitian ini lebih sempurna dan sesuai dengan tujuan penelitian, maka penulis dalam hal ini berusaha menemukan dan mengumpulkan sebanyak mungkin referensi ataupun data seperti buku, majalah, jurnal, internet dan dokumen lain.

Dalam penelitian ini penulis mencari data yang ada kaitannya dengan penelitian untuk dijadikan bahan seperti file Film Tilik, buku, jurnal, penelitian terdahulu dan internet. Penelitian ini bersifat deskriptif karena penelitian ini semata-mata menggambarkan suatu objek untuk mengambil kesimpulankesimpulan yang berlaku secara umum. Dalam penelitian ini penulis akan mendeskripsikan berkaitan dengan pesan dakwah yang terkandung dalam film Tilik dengan menggunakan analisis semiotika Roland Barthes.

Dalam penelitian ini subjek penelitiannya adalah film Tilik karya Wahyu Agung Prasetyo. Objek penelitian dalam penelitian ini adalah makna pesan-pesan dakwah yang meliputi aspek aqidah, syariah, dan akhlak dalam scene-scene film Tilik.

Dalam penelitian ini, untuk menganalisis data yang telah dikumpulkan oleh peneliti, peneliti menggunakan jenis pendekatan kualitatif dengan analisis semitotik yang dikembangkan oleh Roland Barthes yaitu dengan sistem denotasi dan konotasi. Denotasi menggunakan makna dari tanda sebagai definisi secara literal atau nyata. Konotasi mengarah kepada kondisi sosial budaya dan emosional personal. Dalam konsep Barthes, tanda konotasi tidak hanya sekedar memiliki makna tambahan, namun juga mengandung kedua bagian tanda denotative yang dilandasi keberadaannya.

Mitos menurut Barthes terletak pada tingkatan kedua penandaan yaitu setelah terbentuk sistem tanda, penanda, petanda. Tanda tersebut adakan menjadi tanda yang baru. ${ }^{8}$

\section{HASIL DAN PEMBAHASAN}

Penelitian ini menggunakan analisis semiotika Roland Barthes. Semiotika merupakan ilmu yang membahas atau mengkaji mengenai pemaknaan sebuah tanda. Film umunya

\footnotetext{
8 Kurniawan, Semiologi Roland Bathes, (Magelang: Yayasan INDONESITERAA Anggota IKAPI, 2001), 22
}

Hamzani Khairul Ihsan, dkk 229 
Komunike, Volume XIII, No. 2 Desember 2021

mengandung pesan dakwah yang kecil, sedangkan perjalanan mereka disampaikan kepada penonton. Pesan masih jauh. Lalu, Yu Ning tersebut biasanya menggambarkan kehidupan manusia sehari-hari. Ini berkaitan dengan film sebagai miniatur sebuah adegan dalam kehidupan nyata.

Mengingat pentingnya setiap halhal yang menjadi daya Tarik masyarakat terhadap Film Pendek yang berjudul Tilik dan menjadi tranding di salah satu platform Youtube di tinjau aspek keagamaannya, yaitu berupa pesan dakwah dari Film Tilik. Karena penulis belum menemukan penelitian yang benar-benar fokus terhadap analisis semiotika pesan dakwah Film Tilik.

Oleh sebab itu, penulis akan memaparkan analisis semiotika pesanpesan dakwah yang disampaikan melalui film Tilik karya Wahyu Agung Prasetyo untuk memahami pesan dakwah dalam film dapat dilihat dari aspek Akidah, Ibadah, dan Akhlak.

Pesan Akidah, adegan di menit ke (07.40 - 08.00) menggambarkan seorang muslim yang menaruh kepercayaan kepada selain Allah SWT. Tahap Denotatif : Dalam scene ini, terlihat $\mathrm{Bu}$ Tejo tiba-tiba diam. Yu Sam yang merasa heran bertanya kepada Bu Tejo kenapa dia menjadi diam. Ternyata diamnya $\mathrm{Bu}$ Tejo karena ia tidak bisa menahan keinginan untuk buang air 
Pada ayat diatas dapat dipahami bahwa perbuatan syirik merupakan dosa yang paling besar diantara dosa-dosa lainnya dan juga Allah swt tidak akan mengampuni orang-orang yang telah menyekutukannya dengan sesuatu yang lain, dia akan mengampuni dosa-dosa yang lain kecuali dosa syirik. Perbuatan syirik termasuk kedalam kategori pesan dakwah akidah bahwa salah satu ruang lingkup akidah adalah beriman kepada Allah swt. yaitu mempercayai dan menyakini bahwa Allah swt telah mengatur segala sesuatu yang terjadi di dunia ini dan tidak menyekutukan-Nya dengan sesuatu yang lain.

Pesan Syariah (ibadah), Pada adegan di menit ke (09.23-09.35) menggambarkan seorang muslim yang menunda shalatnya. Tahap Denotatif : Dalam scene ini, terlihat Yu Sam turun dari truk dan $\mathrm{Bu}$ Tri memintanya untuk menunggunya. Yu Sam meminta Bu Tri supaya lebih cepat karena shalat dzuhurnya sudah telat dan waktu sudah menunjukkan pukul 02.00 siang. Tahap Konotatif : Dalam scene ini, mengandung makna bahwa Yu Sam dan $\mathrm{Bu}$ Tri tidak melaksanakan shalat sebelum mereka berpergian atau menunda shalatnya. Sehingga mereka menunaikan shalat dzuhurnya tidak tepat waktu. Dalam scene ini, terdapat anjuran untuk menunaikan shalat tepat pada waktunya. Hal ini dijelaskan dalam surat An-nisa ayat 103

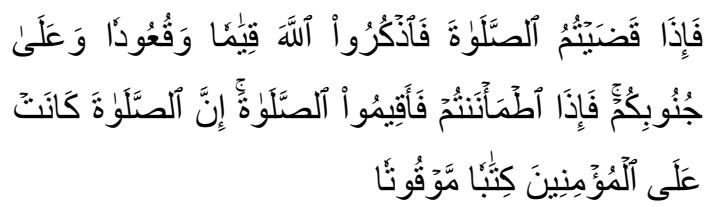

Artinya: "Maka apabila kamu telah menyelesaikan shalat(mu), ingatlah Allah di waktu berdiri, di waktu duduk dan di waktu berbaring. Kemudian apabila kamu telah merasa aman, maka dirikanlah shalat itu (sebagaimana biasa). Sesungguhnya shalat itu adalah fardhu yang ditentukan waktunya atas orang-orang yang beriman"

Pada ayat diatas dapat dipahami bahwa shalat itu merupakan kewajiban bagi setiap muslim dan waktu-waktunya (shalat) itu sudah ditentukan. Jadi dianjurkan kepada umat islam untuk shalat tepat pada waktunya. Shalat di awal waktu adalah amalan yang paling afdhol (utama), sehingga bagi yang suka menunda shalatnya tidak mendapatkan keutamaannya. Melaksanakan shalat tepat waktu termasuk salah satu pesan dakwah syariah bahwa shalat termasuk kedalam ibadah mahdlah (ibadah khusus), yaitu bentuk ibadah hubungan antara manusia dengan Tuhannya.

Pesan Akhlak, Pada scene di menit ke (03:22-04:30) menggambarkan 
seorang muslim yang membicarakan kejelekan orang lain (ghibah). Tahap Denotatif : Dalam scene ini, terlihat Bu Tejo sedang membicarakan tentang kehidupan Dian. Bu Tejo berbicara mengenai Dian yang baru saja bekerja tapi sudah memiliki banyak uang dan bisa membeli barang-barang baru seperti HP dan motor. Padahal kondisi Dian tidak memungkinkan untuk membeli barang-barang tersebut, karena ia dari kecil sudah ditinggalkan bapaknya dan sawah mereka cuma sedikit juga tidak melanjutkan kuliah. Bu Tri kemudian ikut menimpali bahwa Dian tidak mungkin memiliki barang-barang tersebut jika pekerjaannya memang pekerjaan yang baik. Yu Sam yang ikut mendengarkan pun mengiyakan perkataan Bu Tri.

Tahap Konotatif : Dalam scene ini, mengandung makna tentang ghibah. Yaitu memperlihatkan bahwa aktivitas bergosip (ghibah) merupakan hal yang lumrah dalam masyarakat. Disini terlihat $\mathrm{Bu}$ Tejo dan Ibu-ibu lainnya senang membicarakan keburukan dan sibuk mencari-cari keburukan-keburukan yang ada pada Dian. Analisis Dalam scene ini, terdapat larangan melakukan ghibah. Hal ini djelaskan dalam surat Al-Hujurat ayat 12:

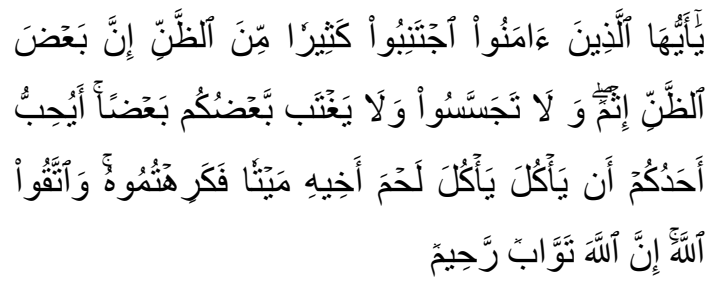

Artinya: "Wahai orang-orang yang beriman! Jauhilah banyak dari prasangka, sesungguhnya sebagian prasangka itu dosa dan janganlah kamu mencari-cari kesalahan orang lain dan janganlah ada di antara kamu yang menggunjing sebagian yang lain. Apakah ada di antara kamu yang suka memakan daging saudaranya yang sudah mati? Tentu kamu merasa jijik. Dan bertakwalah kepada Allah, sesungguhnya Allah Maha Penerima taubat, Maha Penyayang.”

Dari ayat di atas, dapat dipahami bahwa ghibah merupakan perbuatan yang dilarang oleh Allah dan Rasul-Nya. Ghibah termasuk ahklak tercela (akhlak mazmumah), bahkan Allah memberi perumpamaan bagi orang yang melakukan ghibah seperti memakan daging saudaranya yang sudah mati. Oleh karena itu, seorang muslim hendaknya tidak membicarakan keburukan orang lain atau aibnya yang dia (orang yang dibicarakan) tidak suka. Apalagi jika yang dibicarakan ditambahkan dengan cerita sendiri sehingga menimbulkan fitnah. Hukum 
ghibah menurut kesepakatan ulama adalah haram.

\section{E. KESIMPULAN}

Pesan dakwah dalam film "Tilik" setelah dianalisis menggunakan Analisis Semiotika Roland Barthes yaitu dengan sistem denotasi dan konotasi, terdapat beberapa pesan dakwah diantaranya yang diklasifikasikan menjadi tiga kategori yaitu ibadah, aqidah, dan akhlak yang bermanfaat bagi masyarakat dengan meneledani pesan dari film tersebut. Dalam aspek akidah mengenai larangan untuk melakukan perbuatan syirik. Dalam aspek syariah (ibadah) terdapat dalam 2 scene.

Pertama, mengenai anjuran shalat tepat pada waktunya. Kedua, mengenai larangan suap-menyuap. Dalam aspek akhlak terdapat, mengenai anjuran untuk menjenguk orang sakit, mengenai larangan ghibah, mengenai anjuran untuk memeriksa kebenaran suatu informasi (tabayyun), mengenai larangan berprasangka buruk (su'udzon), mengenai anjuran untuk bersabar, mengenai larangan melakukan fitnah, mengenai anjuran untuk saling tolongmenolong, mengenai anjuran untuk menjaga kerukunan atau tidak bertengkar.
Setelah melakukan penelitian dan menganalisis pesan dakwah pada film, maka peneliti memiliki rekomendasi bagi pembuat film Indonesia, agar terus berupaya meningkatkan kreativitas sehingga menghasilkan film-film yang berkualitas, mengandung pesan-pesan yang mendidik dan memberikan nilai positif bagi masyarakat Indonesia. Dan mampu memahami pesan-pesan yang terdapat dalam film dan selektif memilih film yang akan di tonton. Peneliti juga mengharapkan selanjutnya ada penelitian tentang masalah yang serupa sebagai pembanding agar objektivitas karya ini dapat dipertanggung jawabkan. Kedepan akademisi yang memiliki kerangka berpikir kritis dan wawasan yang luas diharapkan dapat memberikan kerangka analisis yang baru dalam hal memahami makna dari pesan media massa terkhusus film.

\section{F. DAFTAR PUSTAKA}

Aditya Ramadhani Tirtamenda, Permainan Bahasa dan Analisis Semiotika Pada Dialog Film Tilik, Jurnal Lugas, Vol. 5 (1), 1-9

Ayesha Muna, 28 Agustus 2020, Melihat perlawanan stereotip perempuan Indonesia di film pendek Tilik, https://theconversation.com/, Diakses 06 Juli 2021

Bambang S, Ma'arif. Komunikasi Dakwah, Simbiosa Rekatama Media: 2010. 
Dian Bagus Mitreka Satata, Methania Aris Shusantie, Analisis Hubungan Interpersonal dalam Film Tilik pada Persfektif Psikologis, Dinamika Sosial Budaya, Jurnal Vol. 23 (1) 108-114

Dwi Ratih Puspitasari, Nilai Sosial Budaya dalam Film Tilik (Kajian Semiotika Charles Sanders Peirce), Jurnal Semiotika, Vol. 15 (1), 1018

Ela Indah Dwi Syayekti, Feminisme dalam Film Pendek "Tilik" (Analisis Semiotika John Fiske), Skipsi, IAIN Ponorogo,

Fitri, Saidatina. "Pesan-pesan Dakwah Dalam Film Negeri 5 Menara (Suatu Kajian Content Analysis)". Skripsi. Fakultas Dakwah dan Komunikasi. Jurusan Jurnalistik. Universitas Islam Negeri Alauddin Makassar, 2017.

Kurniawan, Semiologi Roland Bathes, Magelang: Yayasan Indonesiteraa Anggota IKAPI, 2001.

Latifah, Nurul. "Analisis Semiotik Pesan Dakwah dalam Film "Bulan Terbelah di Langit Amerika" Skripsi. Fakultas Ilmu Dakwah dan Ilmu Komunikasi. Jurusan Komunikasi dan Penyiaran Islam. Universitas Islam Negeri Syarif Hidayatullah Jakarta, 2016.

M. Munir \& Wahyu Ilaihi, Manajemen Dakwah, Jakarta: Kencana, 2006.

Mohamad Ihwan Fikri, "Pesan Dakwah Dalam Film Hafalan Sholat Delisa Karya Sony Gaokasak", Skripsi, Fakultas Dakwah dan Ilmu Komunikasi, Jurusan Komunikasi dan Penyiaran Islam, 2019.

Mustofa, M. B., Wuryan, S., Sholiha, N. A., Arif, M. M., \& Musa, M. (2021). Kontribusi Komunikasi Interpersonal dalam Perspektif Islam di Lingkungan Organisasi
UIN Raden Intan Lampung. Komunikasia: Journal of Islamic Communication and Broadcasting, 1(1), 56-68.

Nurul Latifah, "Analisis Semiotika Pesan Dakwah Dalam Film Bulan Terbelah di Langit Amerika", Skripsi, Fakultas Dakwah dan Ilmu Komunikasi, Jurusan Komunikasi dan Penyiaran Islam, 2016.

Purnamasari, Wina. "Film Jilbab Traveler: Love Spark In Korea Dalam Analisis Komunikasi Dakwah". Skripsi. Fakultas Dakwah dan Ilmu Komunikasi. Jurusan Komunikasi dan Penyiaran Islam. Universitas Islam Negeri Raden Intan Lampung. 2019.

Saputra, Johadi. Pesan Dakwah Dalam Film 3 Hati Dua Dunia Satu Cinta Karya Beni, 2017.

Setiawan (Study Analisis Semiotika Teori Roland Barthes)". Skripsi, Fakultas Dakwah dan Ilmu Komunikasi. Jurusan Komunikasi dan Penyiaran Islam. Universitas Islam Negeri Raden Intan Lampung.

Tika Destiana, Analsis Semiotika Makna Ghibah dalam Film Pendek Tilik di Youtube Racana Film, Skripsi UIN Syarif Hidayatullah Jakarta.

Wahyudianto, Amri. "Pesan Dakwah Pada Web Series Ramadhan Halal 2016 Episode 1-4 di Youtube Dalam Analisis Semiotika Roland Barthes". Skripsi. Fakultas Dakwah dan Ilmu Komunikasi. Jurusan Komunikasi dan Penyiaran Islam. Universitas Islam Negeri Raden Intan Lampung, 2017. 